\title{
Prevalence of smoking in nursing professionals of a cardiovascular hospital
}

\author{
Prevalência do tabagismo em profissionais de enfermagem de um hospital cardiovascular \\ Prevalencia del tabaquismo en profesionales de enfermería en un hospital cardiovascular
}

\section{Andrea Cotait Ayoub' \\ ORCID: 0000-0003-0981-6287 \\ Márcio Gonçalves Sousa' \\ ORCID: 0000-0001-5460-5476}

'Instituto Dante Pazzanese de Cardiologia. São Paulo, São Paulo, Brazil.

How to cite this article:

Ayoub AC, Sousa MG. Prevalence of smoking in nursing professionals of a cardiovascular hospital. Rev Bras Enferm [Internet]. 2019;72(Suppl 1):173-80. [Thematic Issue: Work and Management in Nursing]. DOI: http://dx.doi.org/10.1590/0034-7167-2018-0145

\section{Corresponding Author: \\ Andrea Cotait Ayoub \\ E-mail: andreacotaitayoub@gmail.com}

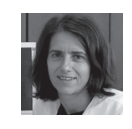

Submission: 03-16-2018

Approval: 05-16-2018

\begin{abstract}
Objective: to identify the prevalence of smoking in nursing professionals and to determine the relationship of the habit with clinical and socio-demographic characteristics. Method: nursing professionals of a cardiovascular hospital answered a questionnaire on smoking and dependence degree, socio-demographic characteristics, personal and family background, smoking characteristics, motivational stages, depression, perceived and occupational stress. The relationship between the explanatory variables and smoking was investigated. Results: among 656 participants, $77.6 \%$ were non smokers, 12.2\% former smokers, and $10.2 \%$ smokers. Most were female, with complete high school, Catholic, married, household income between three and five minimum wages, position as nursing assistant, had double shifts, and were responsible for family income. The nicotine dependence of smokers ranged from low to moderate. Conclusion: the study has shown low prevalence of smoking in nursing professionals. Education level, religion, marital status, job position, responsibility for family income, history of depression and alcoholism, chest "wheezing" and other symptoms were significantly associated with being a smoker or former smoker.

Descriptors: Tobacco Use Cessation; Cardiovascular Nursing; Nurses; Health of Workers; Smoking.
\end{abstract}

\section{RESUMO}

Objetivo: identificar a prevalência do tabagismo em profissionais de enfermagem e determinar relações do hábito com características sociodemográficas e clínicas. Método: profissionais de enfermagem de um hospital cardiovascular responderam ao questionário sobre tabagismo e grau de dependência, características sociodemográficas, antecedentes pessoais e familiares, características do tabagismo, estágios motivacionais, depressão, estresse percebido e ocupacional. Investigou-se a relação entre as variáveis explicativas e tabagismo. Resultados: dentre 656 participantes, identificaram-se 77,6\% não tabagistas, $12,2 \%$ ex-tabagistas e 10,2\% tabagistas. A maioria era mulher, com ensino médio completo, católica, casada, renda familiar entre três e cinco salários-mínimos, cargo de auxiliar de enfermagem, tinha dupla jornada e era responsável pela renda familiar. Tabagistas tinham dependência nicotínica de baixa a moderada. Conclusão: o estudo demonstrou baixa prevalência de tabagismo em profissionais de enfermagem. Escolaridade, religião, estado civil, cargo, responsabilidade pela renda familiar, história pessoal de depressão e etilismo, ter pais tabagistas, chiado no peito e outros sintomas associaram-se significativamente a ser tabagista e ex-tabagista.

Descritores: Abandono do Uso de Tabaco; Enfermagem Cardiovascular; Profissionais de Enfermagem; Saúde do Trabalhador; Tabagismo.

\section{RESUMEN}

Objetivo: identificar la prevalencia del tabaquismo en profesionales de enfermería y determinar relaciones del hábito con características sociodemográficas y clínicas. Método: los profesionales de enfermería de un hospital cardiovascular respondieron al cuestionario sobre el tabaquismo y el grado de dependencia, características sociodemográficas, antecedentes personales y familiares, las características del tabaquismo, etapas de motivación, depresión y estrés laboral percibido. Se investigó la relación entre las variables explicativas y el tabaquismo. Resultados: entre los 656 participantes, se identificaron un $77,6 \%$ no tabaquistas, un $12,2 \%$ ex tabaquistas y un $10,2 \%$ tabaquistas. La mayoría era mujer, con enseñanza media completa, católica, casada, ingreso familiar entre tres y cinco salarios mínimos, cargo de auxiliar de enfermería, tenía doble jornada y era responsable por la renta familiar. Los tabaquistas tenían dependencia nicotínica de baja a moderada. Conclusión: el estudio demostró baja prevalencia del tabaquismo en profesionales de enfermería. La escolaridad, la religión, el estado civil, el cargo, la responsabilidad por la renta familiar, la historia personal de la depresión y el etilismo, tener padres tabaquistas, chillidos en el pecho y otros síntomas se asociaron significativamente a ser tabaquista y ex tabaquista.

Descriptores: Cese del Uso de Tabaco; Enfermería Cardiovascular; Enfermeras Practicantes; Salud Laboral; Tabaquismo. 


\section{INTRODUCTION}

Smoking is one of the most important public health problems in the world ${ }^{(1-2)}$. Regarded as an epidemic disease, it exposes individuals to more than 7,000 toxic substances that are risk factors for many chronic non-communicable diseases ${ }^{(2)}$, such as cancer, respiratory and cardiovascular diseases, among others ${ }^{(2-6)}$, persisting as one of the leading preventable causes of death ${ }^{(2,7)}$.

Worldwide, approximately 7 million people die each year due to smoking-related diseases, and projections point that in 2030 this number will surpass 8 million per year, and half the deaths will be of individuals in productive age ${ }^{(1)}$. Only in Brazil, in 2015, 156,216 deaths were caused by tobacco use, i.e., eighteen deaths per hour, representing $12.6 \%$ of the total deaths in the country. Of these, $16 \%$ are related to cardiovascular diseases and $13 \%$ is due to cerebrovascular accidents ${ }^{(3)}$.

The frequency of adult smokers in the 26 Brazilian States and the Federal District ranges between 5.1\% in Salvador and $14.0 \%$ in Curitiba ${ }^{(5)}$. In the country, $52 \%$ of the smokers are planning to quit smoking ${ }^{(1)}$ and, regardless of the difficulties associated with smoking cessation, the frequency of smokers has decreased on average by 0.62 percentage points per year between 2006 and $2016^{(5)}$.

The difficulty in quitting smoking relates to the organic dependence and, probably, to the same reasons associated with experimentation and starting smoking: rebellious behavior, need to show maturity, imitate an idol, pressure from smoking peers or family, association of smoking with people well resolved from a professional, financial and sexual point of view, as well as neuropsychological characteristics of the individual ${ }^{(8-9)}$.

Since the concern about health is the main motivation to stop smoking, questions arise regarding the maintenance of smoking habits amongst professionals of the hospital area, as most of them have formal education in the field of Health and, therefore, knowledge on the damages caused by cigarettes ${ }^{(10-12)}$. In a sample of 175 professionals from a University hospital, $20 \%$ were former smokers and $13.6 \%$ were smokers ${ }^{(13)}$. Among nursing workers, the occurrence of smoking ranges from $4.6^{(14)}$ to $7.1 \%{ }^{(15)}$ and the prevalence of former smokers ranges from $12.8 \%^{(14)}$ to $25.7 \%{ }^{(15)}$.

\section{OBJECTIVE}

To identify the prevalence of smoking in nursing professionals and determine the relationships of the habit with clinical and socio-demographic characteristics.

\section{METHOD}

\section{Ethical aspects}

The study was submitted to the Committee of Ethics and Research with Humans Beings (CEP) of the Dante Pazzanese Institute of Cardiology, in São Paulo, and follows the ethical principles contained in the Declaration of Helsinki. Professionals were ensured of their anonymity and freedom to leave the study at any time.

\section{Design, location and period}

This is an analytical cross-sectional study of a quantitative approach, carried out between March and September 2016 in a large public institution in the State of São Paulo, which specializes in the cardiovascular area and is dedicated to caring, management, teaching, and research.

\section{Sample: inclusion and exclusion criteria}

Were considered eligible 763 nurses, nursing technicians and assistants from all sectors of the institution. Were excluded those who were not active in the period of data collection, like those on health leave, and those who have not returned the filled form within twenty days and or did not sign the Informed Consent Form (ICF). The total of participants included in the study amounted to 656 .

\section{Study protocol}

The lead researcher invited professionals to participate in the study, explained the research objectives, and requested the ICF signature. Each participant was given an envelope containing self-filling forms and questionnaires for data collection. It was requested that forms were returned filled within up to ten days, with a maximum tolerance of twenty days.

Smoking was considered the dependent variable, according to the groups: nonsmoker, former smoker (at least twelve months without smoking) or smoker.

For those who declared themselves as smokers and former smokers, the nicotine dependence degree was investigated through the Fagerström Test of Nicotine Dependence (FTND) ${ }^{(16)}$, a questionnaire containing six questions of simple choice, whose score is categorized as: 0 to 2 (very low); 3 to 4 (low); 5 (moderate); 6 to 7 (high); 8 to 10 (very high).

Smokers were questioned about their reasons for maintaining the habit, with the options of liking smoking, anxiety, and nicotine dependence. For former smokers, the time of abstinence was questioned.

Independent variables of interest to the study and their respective evaluation tools were:

- Socio-demographic and professional, evaluated through a form prepared by the researchers: religion, age, gender, education level, marital status, household income, responsibility for the household income, position in the institution.

- Personal and family backgrounds, evaluated through a form prepared by the researchers: cancer, depression, chronic obstructive pulmonary disease, "wheezing," alcoholism, use of illicit drugs, the opinion of the significant other about smoking, others.

- Characteristics of smoking, evaluated through a form prepared by the researchers: age f tobacco use onset, time of use, number of cigarettes per day, participation in any smoker support program.

- Motivational stages and readiness for change regarding psychoactive substances, evaluated through the University of Rhode Island Change Assessment Urica-24 (reduced version) ${ }^{(17)}$, consisting of 24 items divided into four subscales, each with six items: pre-contemplation, contemplation, action, and maintenance. Responses are given in ranges from 1 (extremely disagree) to 5 (completely agree). Each statement is linked to a different motivational stage. 
- The intensity of depression, measured using the Beck Depression Inventory $(\mathrm{BDI})^{(18)}$, a questionnaire of 21 statements that categorizes patients by scores: from 0 to 14 (no depression symptoms); 15 to 19 (dysphoria symptoms) from 20 (depression symptoms).

- Perceived stress, evaluated through the Perceived Stress Scale-10 (PSS-10) ${ }^{(19)}$.It addresses thoughts and feelings experienced in the daily life, regardless of occurring or not in the work environment. The Scale consists of ten items, and its assessment is made as follows: 0 (never); 1 (almost never); 3 (almost always); 4 (always). Then, all items are summed, with a total score ranging from 0 to 40 . The higher the score, the greater the stress.

- Overall occupational stress, measured by the Work Stress Scale (WSS) ${ }^{(20)}$, composed of 23 questions about psychosocial factors identified as organizational stressors and emotional reactions before them. Participants respond on a scale ranging from 1 (strongly disagree) to 5 (completely agree). The score ranges from 23 to 115 . The higher the score, the greater the stress.

\section{Analysis of the results and statistics}

In the descriptive analysis, was used the Statistical Package for the Social Sciences (IBM-SPSS) version 19.0 (SPSS Institute, Chicago, Illinois). For quantitative variables, mean and standard deviation (SD) were used and, for the categorical variables, absolute (n) and relative (\%) frequencies. To evaluate the relationship between background variables and smoking, we used Fisher's exact test. Finally, the posttest of residue analysis was conducted on the results obtained ${ }^{(21)}$.

\section{RESULTS}

The population consisted of 656 participants, 509 (77.6\%) nonsmokers, 80 (12.2\%) former smokers, and 67 (10.2\%) smokers.

Among smokers, the mean Fagerström score was $4.84 \pm 1.60$ (low to moderate dependence), whereas for former smokers the mean was $4.0 \pm 3.0$ (low), there is no significant difference $(P=0.606)$. Most smokers $(n=26 ; 38.8 \%)$ used to light the first cigarette of the day between six and thirty minutes after waking, while thirteen others (19.4\%) did it in less than five minutes after waking; twelve (17.9\%) between 31 and 60 minutes; sixteen (23.9\%) smoked more than one hour after waking.

Most smokers kept the habit because they like smoking $(n=47$; $32.0 \%)$, followed by those who declared anxiety ( $n=12 ; 8.2 \%)$ and nicotine dependence $(n=8 ; 5.4 \%)$. Among former smokers, most were on abstinence for more than ten and less than fifteen years $(n=38 ; 25.9 \%)$, followed by those who stopped smoking for more than five years $(n=19 ; 12.9 \%)$; more than one and less than five years $(n=12 ; 8.2 \%)$, and less than twelve months $(n=10 ; 6.8 \%)$.

According to Table 1, most were female, with complete high school, Catholic, married, household income between three and five minimum wages, position as nursing assistant, had more than one work in the area, and were responsible for the household income. Regarding the time working in the institution, the mean was 8.5 years (minimum of six months and a maximum of 42 years).

Socio-demographic variables significantly associated with smoking were education level, religion, marital status, job position, and responsibility for the household income (Table 1).

Table 1 - Socio-demographic characterization of nursing professionals of the hospital are according to smoking (n=656), São Paulo, Brazil, 2016

\begin{tabular}{|c|c|c|c|c|c|}
\hline Variables & Total & $\begin{array}{c}\text { Non-smokers } \\
n=509\end{array}$ & $\begin{array}{c}\text { Former smokers } \\
\qquad n=80\end{array}$ & $\underset{n=67}{\text { Smokers }}$ & $p$ value \\
\hline Age (years), mean $\pm S D$ & $42.3 \pm \mathrm{DP}$ & $43.2 \pm 7.6$ & $47.7 \pm 8.8$ & $41 \pm 9.5$ & 0.084 \\
\hline Female $\mathrm{n}(\%)$ & $526(81.7)$ & $415(81.5)$ & $59(73.8)$ & $52(77.6)$ & 0.224 \\
\hline Education level n(\%) & & & & & 0.002 \\
\hline Complete High school & $86(13.1)$ & $64(12.6)$ & $9(11.3)$ & 13(19.4) & \\
\hline Some Technical Education & $3(5)$ & $2(0.4)$ & 0 & $1(1.5)$ & \\
\hline Complete Technical Education & $184(28)$ & $137(26.9)$ & $24(30.0)$ & $23(34.3)$ & \\
\hline Some Higher Education & $91(13.9)$ & $68(13.4)$ & $11(13.8)$ & $12(17.9)$ & \\
\hline Complete Higher Education & $89(13.6)$ & $61(12.0)$ & $17(21.3)$ & $11(16.4)$ & \\
\hline Graduate studies & $203(30.9)$ & $177(34.8)$ & $19(23.8)$ & $7(10.4)$ & \\
\hline Religion & & & & & $<0.001$ \\
\hline Catholic & $303(46.9)$ & $225(44.7)$ & $45(56.3)$ & $33(50.8)$ & \\
\hline Evangelic & $174(26.9)$ & 154(30.6) & $15(19.2)$ & $5(7.7)$ & \\
\hline Buddhist & $8(1.2)$ & $7(1.4)$ & 0 & $1(1.5)$ & \\
\hline Jehovah's witness & $12(1.9)$ & $12(2.4)$ & 0 & 0 & \\
\hline Spiritualist & $91(14.1)$ & $62(12.3)$ & $14(17.9)$ & $15(23.1)$ & \\
\hline Other & $58(9)$ & $43(8.5)$ & $4(5.1)$ & 11(16.9) & \\
\hline Marital status n(\%) & & & & & $<0.001$ \\
\hline Single & 194(29.6) & $158(31.0)$ & $12(15.0)$ & $24(35.8)$ & \\
\hline Married & $290(44.2)$ & $238(46.8)$ & $35(43.8)$ & $17(25.4)$ & \\
\hline Divorced & $85(13)$ & $58(11.4)$ & $16(20.0)$ & $11(16.4)$ & \\
\hline Widowed & $19(2.9)$ & $10(2.0)$ & $4(5.0)$ & $5(7.5)$ & \\
\hline Living with a partner & $68(10.4)$ & $45(8.8)$ & $13(16.3)$ & $10(14.9)$ & \\
\hline
\end{tabular}




\begin{tabular}{|c|c|c|c|c|c|}
\hline Variables & Total & $\begin{array}{c}\text { Non-smokers } \\
n=509\end{array}$ & $\begin{array}{c}\text { Former smokers } \\
\qquad=80\end{array}$ & $\begin{array}{c}\text { Smokers } \\
n=67\end{array}$ & $p$ value \\
\hline Household income, $\mathrm{n}(\%)$ & & & & & 0.502 \\
\hline 1 to $3 \mathrm{MW}$ & $121(18.4)$ & $95(18.7)$ & $14(17.5)$ & $12(17.9)$ & \\
\hline More than 3 to $5 \mathrm{MW}$ & $276(42.1)$ & 209(41.1) & $35(43.8)$ & $32(47.8)$ & \\
\hline More than 5 to $7 \mathrm{MW}$ & $105(16)$ & $79(15.5)$ & $14(17.5)$ & $12(17.9)$ & \\
\hline More than 7 to $9 \mathrm{MW}$ & $74(11.3)$ & $64(12.6)$ & $4(5)$ & 6(9) & \\
\hline More than $9 \mathrm{MW}$ & $80(12.2)$ & $62(12.2)$ & $13(16.3)$ & $5(7.5)$ & \\
\hline Position n (\%) & & & & & 0.027 \\
\hline Assistant & $351(53.5)$ & $265(52.1)$ & $41(51.3)$ & $45(67.2)$ & \\
\hline Technician & $122(18.6)$ & $90(17.7)$ & $19(23.8)$ & $13(19.4)$ & \\
\hline Nurse & $183(27.9)$ & $154(30.3)$ & $20(25.0)$ & $9(13.4)$ & \\
\hline Working time in the institution (years) mean $\pm S D$ & $8.5 \pm 7.4$ & $8.2 \pm 7.2$ & $10.6 \pm 9$ & $8.5 \pm 6.7$ & 0.087 \\
\hline Jobs in the area $\mathrm{n}(\%)$ & & & & & 0.141 \\
\hline One & $420(66.2)$ & $317(65)$ & $52(65)$ & $51(77.3)$ & \\
\hline More than one & $222(33.8)$ & $171(35)$ & $28(35)$ & $15(22.7)$ & \\
\hline Work shift & & & & & 0.113 \\
\hline Morning & 243(37) & $195(38.3)$ & $32(40.0)$ & $16(23.9)$ & \\
\hline Afternoon & $187(28.5)$ & $142(27.9)$ & $18(22.5)$ & $27(40.3)$ & \\
\hline Night & 197(30) & $152(29.9)$ & $24(30.0)$ & $21(31.3)$ & \\
\hline Daytime $12 / 36 \mathrm{~h}$ & $29(4.4)$ & 20(3.9) & $6(7.5)$ & $3(4.5)$ & \\
\hline Responsible for income $\mathrm{n}(\%)$ & & & & & 0.021 \\
\hline Own professional & $344(53.1)$ & $255(50.6)$ & $44(56.4)$ & $45(68.2)$ & \\
\hline Children, spouse, couple, other & $304(46.9)$ & $249(49.4)$ & $34(43.6)$ & $21(31.8)$ & \\
\hline
\end{tabular}

Note: SD (standard deviation); MW (minimum wage).

Different associations were obtained with the post-test of residue. A high education level was associated with a lower prevalence of smoking ( $p<0.001)$. As to religious belief, the Evangelism was associated with nonsmoking ( $p<0.001)$, Catholicism to former smoking ( $p=0.046)$; and Spiritualism ( $p=0.028)$ and other groups (agnostic, Christian, eclectic, Universalist, Umbanda, and Judaism) $(p=0.016)$ to smoking. Regarding marital status, marriage was associated with the group of nonsmokers $(p=0.014)$, divorce was related to former smokers $(p=0.045)$ and widowed status to smoking $(p=0.019)$. Nursing assistants are more common among smokers $(p=0.018)$. Finally, individuals who declared themselves as the single responsible for the household income had a higher prevalence of smoking than those who had the heal of other family members $(p=0.013)$.

Table 2 - Characteristics of smoking among nursing professionals of the hospital area ( $N=147)$, São Paulo, Brazil, 2016

\begin{tabular}{|c|c|c|c|c|c|c|c|}
\hline \multirow[t]{2}{*}{ Variable } & \multicolumn{2}{|c|}{$\begin{array}{c}\text { Total } \\
\mathrm{N}=147\end{array}$} & \multicolumn{2}{|c|}{$\begin{array}{c}\text { Former smokers } \\
\qquad \mathbf{n}=\mathbf{8 0}\end{array}$} & \multicolumn{2}{|c|}{$\begin{array}{c}\text { Smokers } \\
\mathrm{n}=67\end{array}$} & \multirow[t]{2}{*}{$p$ value } \\
\hline & $\mathbf{n}$ & $\%$ & $\mathbf{n}$ & $\%$ & $\mathbf{n}$ & $\%$ & \\
\hline Age started smoking & & & & & & & 0.521 \\
\hline Up to 15 years old & 47 & 32.0 & 27 & 35.1 & 20 & 29.9 & \\
\hline $16-24$ years old & 88 & 59.9 & 44 & 57.1 & 44 & 65.7 & \\
\hline$<24$ years old & 9 & 6.1 & 06 & 7.8 & 3 & 4.5 & \\
\hline \multicolumn{8}{|l|}{ Time of smoking } \\
\hline$<10$ years & 56 & 38.1 & 31 & 47.7 & 25 & 37.0 & \\
\hline $11-20$ years & 60 & 40.8 & 26 & 40.0 & 34 & 52.0 & \\
\hline $21-30$ years & 9 & 6.1 & 5 & 7.7 & 4 & 6.0 & \\
\hline $31-40$ years & 6 & 4.1 & 3 & 4.6 & 3 & 4.0 & \\
\hline$>40$ years & & & - & - & 1 & 1.0 & \\
\hline \multicolumn{8}{|l|}{ Number of cigarettes consumed/day } \\
\hline 20/day & 120 & 81.6 & 64 & 84.2 & 56 & 84.8 & 1.00 \\
\hline $21-30 /$ day & 17 & 11.6 & 9 & 11.8 & 8 & 12.1 & \\
\hline 31-40/day & 5 & 3.4 & 3 & 3.9 & 2 & 3.0 & \\
\hline Smoking cessation attempts through therapy & & & & & & & 0.106 \\
\hline Never & 47 & 32.0 & 25 & 32.9 & 22 & 34.9 & \\
\hline 1 time & 27 & 18.4 & 14 & 18.4 & 13 & 20.6 & \\
\hline $2-3$ times & 37 & 25.2 & 18 & 23.7 & 19 & 30.2 & \\
\hline$>4$ times & 28 & 19.0 & 19 & 25.0 & 9 & 14.3 & \\
\hline
\end{tabular}


Table 3 - Personal and family background among nursing professionals of the hospital area in relation to smoking (N=656), São Paulo, Brazil, 2016

\begin{tabular}{|c|c|c|c|c|c|c|c|}
\hline \multirow[t]{2}{*}{ Variables } & \multicolumn{2}{|c|}{$\begin{array}{c}\text { Total } \\
(\mathrm{N}=656)\end{array}$} & \multicolumn{2}{|c|}{$\begin{array}{c}\text { Nonsmokers } \\
n=509\end{array}$} & \multicolumn{2}{|c|}{$\begin{array}{c}\text { Former smokers/ } \\
\text { Smokers } \\
n=147\end{array}$} & \multirow[t]{2}{*}{$p$ value } \\
\hline & $\mathbf{n}$ & $\%$ & $\mathbf{n}$ & $\%$ & $\mathbf{n}$ & $\%$ & \\
\hline Personal history of neoplasia & 223 & 34.0 & 169 & 33.2 & 54 & 36.7 & 0.431 \\
\hline Personal history of depression & 113 & 17.2 & 80 & 15.7 & 33 & 22.6 & 0.064 \\
\hline Personal history of drug use & 21 & 3.2 & 14 & 2.8 & 7 & 4.8 & 0.283 \\
\hline Personal history of alcoholism & 64 & 9.8 & 39 & 7.7 & 25 & 17.1 & 0.001 \\
\hline Father smoker & 237 & 36.1 & 168 & 33.2 & 69 & 46.9 & 0.003 \\
\hline Mother smoker & 138 & 21.0 & 90 & 17.8 & 48 & 32.7 & $<0.001$ \\
\hline Significant other against smoking & 489 & 74.5 & 393 & 77.2 & 96 & 65.8 & 0.007 \\
\hline Chronic obstructive pulmonary disease & 23 & 3.5 & 16 & 3.2 & 7 & 4.8 & 0.321 \\
\hline Chest "wheezing" & 28 & 4.3 & 17 & 3.3 & 11 & 7.5 & 0.037 \\
\hline Other symptoms & 42 & 6.4 & 24 & 4.7 & 18 & 12.2 & 0.002 \\
\hline
\end{tabular}

Table 4 - Scores of the Perceived Stress Scale-10, Work Stress Scale, and Beck's Depression Inventory of nursing professionals of the hospital area in relation to smoking ( $\mathrm{N}=656)$, São Paulo, Brazil, 2016

\begin{tabular}{|c|c|c|c|c|c|}
\hline Variables & $\begin{array}{c}\text { Total } \\
(\mathrm{N}=656)\end{array}$ & $\begin{array}{c}\text { Nonsmokers } \\
n=509\end{array}$ & $\begin{array}{l}\text { Former smokers } \\
\qquad \mathrm{n}=\mathbf{8 0}\end{array}$ & $\begin{array}{c}\text { Smokers } \\
n=67\end{array}$ & $p$ value \\
\hline Perceived stress & $12.9 \pm 4.9$ & $12.74 \pm 4.98$ & $13.50 \pm 4.41$ & $13.36 \pm 4.82$ & 0.162 \\
\hline Overall Occupational Stress & $46.4 \pm 15.7$ & $46.19 \pm 15.47$ & $49.01 \pm 16.46$ & $45.33 \pm 16.52$ & 0.319 \\
\hline Intensity of depression & $6.0 \pm 5.8$ & $5.95 \pm 5.82$ & $6.13 \pm 5.17$ & $6.69 \pm 6.14$ & 0.448 \\
\hline
\end{tabular}

Among smokers and former smokers, most started smoking between 16 and 24 years of age, smoked for eleven to twenty years, twenty cigarettes per day, and never tried to quit smoking through therapy (Table 2).

History of depression and alcoholism, having smoking parents, chest "wheezing" and other symptoms were significantly associated with being a smoker or former smoker, when compared to nonsmokers. Having a significant other who is against smoking, in turn, was significantly associated with being a nonsmoker (Table 3).

Regarding motivational stages and readiness for change, there were some significant differences between smokers and former smokers. Concerning the statement 8 of Urica (Working hard to change the behavior with respect to cigarettes), former smokers fully agreed, whereas smokers disagreed $(P=0.002)$. As for item 10 (I need to do something to prevent a relapse), former smokers fully agreed ( $\mathrm{P}=0.002)$, as well as regarding items 11 (I am working on changing my behavior with respect to cigarettes) $(\mathrm{P}<0.001)$ and 18 (I am doing something regarding my cigarette problem) $(\mathrm{P}=0.019)$.

The professionals had no signs of depression nor presented significant differences among themselves. Levels of perceived and occupational stress also did not differ between groups (Table 4).

\section{DISCUSSION}

This study found a low prevalence of smoking and former smoking among nursing professionals of a hospital institution, coinciding with the variation found in Brazilian studies ${ }^{(14-15)}$. In addition, professionals who smoked had a low to moderate degree of habit dependence, which is also compatible with answers of the participants regarding habit maintenance, as few of them considered themselves as nicotine dependents.
Studies have shown that individuals with less schooling present a prevalence of smoking up to 2.39 times higher than those of higher education level ${ }^{(22-27)}$, since education provides greater knowledge about individual health and, therefore, allows to recognize the risks of smoking. This reality is corroborated in this study, since nursing assistants and technicians, positions that do not require higher education, reported smoking more than nurses, who have higher education.

Previous studies showed that religious affiliation or practice reduces in 39\% the risk of exposure to tobacco use, reaching a reduction of $72 \%$ when comparing evangelicals with those without religious affiliations or practices ${ }^{(28-29)}$. This association emerges, at least partially, from doctrines adopted and transmitted by these denominations, prohibiting practices that are harmful to health, such as smoking and alcoholism ${ }^{(29)}$. Similarly, in this study, evangelicals showed a lower prevalence of smoking in comparison with professionals from other religions.

In addition to education level, lower-income individuals present prevalence of smoking 2.15 times higher than the highest income group $^{(22-23,30-31)}$. In this study, smokers, when compared to former and nonsmokers, were more frequently the sole responsible for household income. Nevertheless, this factor was not significant for the prevalence of smoking since the mean household income seemed relatively consistent among the subjects of the research, regardless of position held, due to the double work shift of assistants and technicians.

Stress is considered an important risk factor for smoking, as the act of smoking is described by smokers as relaxing ${ }^{(18,25)}$. Work-related stress is a condition capable of generating health, physical and mental problems, and may lead to the excessive consumption of tobacco ${ }^{(32-33)}$. Furthermore, a study conducted 
with Portuguese health professionals identified that nurses showed levels of stress relatively higher than those of other professionals of the area ${ }^{(32)}$. However, in this study, there was no significant difference between the stress levels of nonsmokers, former smokers, and smokers.

Just like stress, the depression also increases the risk of nicotine dependence, and this association increases twice the risk of heart disease. The risk of relapse varies according to the time of tobacco use, the start of consumption, and depression because these factors make it difficult to abandon the habit ${ }^{(34)}$. Stopping smoking is associated with the reduction of depression, anxiety, stress, and to improvements in quality of life when compared to individuals who maintain the smoking habits ${ }^{(6)}$. This study, however, did not reveal a statistically significant difference between the prevalence of depression among nonsmokers, former smokers, and smokers.

The age of tobacco use onset occurs predominantly between twelve and eighteen years of age $\mathrm{e}^{(13,25,35-36)}$. A study that compared habits, knowledge and attitudes of doctors and nurses of the primary care identified similarity in the age of smoking initiation among these professionals ${ }^{(37)}$. Furthermore, having a father and mother smokers increases the chance of smoking in almost 2.2 times between young people from 15 to 24 years of age ${ }^{(38)}$, age at which most of the participants of this study started smoking.

The time that the individual takes to smoke the first cigarette soon after waking and the number of cigarettes consumed per day are important indicators of the nicotine dependence degree. It is also well known that the higher the dependence, the more difficult it is to stop smoking, due to symptoms of withdrawal. This study identified that most smokers used to light the first cigarette of the day between six to thirty minutes after waking and smoked twenty cigarettes per day. Different results showed that most smokers light the first cigarette of the day one hour after waking and smoke from one to ten cigarettes per day ${ }^{(26)}$.

Quitting smoking is linked, among other factors, to the level of motivation and readiness of the own individual to do as such. Based on the results of the Urica test, it was found that nursing professionals who were former smokers had a greater concern and commitment to not smoke than the group of smokers. Even so, there was no significant difference between the number of attempts to stop the habit between smokers and former smokers. These results resemble those obtained by a previous study, which found that $84.9 \%$ of abstainers tried to cease using tobacco, whereas $82.6 \%$ of the smokers also made attempts. However, regardless of the success of smoking cessation, a few reported that they never made any attempt, $15.1 \%$ of abstainers and $17.4 \%$ of smokers ${ }^{(39)}$.

In addition to individual motivation and readiness, the smoking cessation was also associated, in a previous study, with the presence of a spouse or cohabitant who is a nonsmoker or contrary to smoking ${ }^{(40)}$. It is known that the family, especially parents and siblings, has a strong influence on the initiation of smoking(41). In the sample studies, the fact of the participants' significant others were against smoking was also more frequent among former smokers.

\section{Study limitations}

Certain limitations should be considered in the interpretation of results. Since the data were self-reported and the participants were professionals of the institution, the findings may have been underestimated, as the informants could suppose they would be harmed in the working environment due to their answers, as well as because of the use of licit and illicit drugs.

\section{Contributions to the field of Nursing}

The results demonstrate the need for rethinking and establishing new programs of health promotion and prevention that address the various socio-demographic and individual factors linked to smoking, to enable the reduction of this prevalence among nursing professionals.

\section{CONCLUSION}

The findings showed a low prevalence of smoking among nursing professionals. However, formal education in the area of Health and knowledge about the harms caused by the cigarette was not important to reduce the prevalence of the habit among these professionals.

Having a low education level, not professing any religion, being single, working as a nursing assistant, being the sole responsible for the household income, having a personal history of depression and alcoholism, having parent smokers, and presenting chest "wheezing" and other symptoms are significantly associated with being a smoker or former smoker.

\section{REFERENCES}

1. WHO Report on the Global Tobacco Epidemic, 2011: warning about the dangers of tobacco. [Internet]. 2011. Geneva: World Health Organization; 2011 [cited 2018 Aug 9]. Available from: http://whqlibdoc.who.int/publications/2011/9789240687813_eng.pdf

2. Choi SH, Kim YH. Factors affecting Korean registered nurses intention to implement smoking cessation intervention. Osong Public Health Res Perspect [Internet]. 2016 [cited 2018 Aug 9 7];7(1):63-70. Available from: https://www.sciencedirect.com/science/article/pii/ S221090991530059X?via\%3Dihub

3. Pinto MT, Pichon-Riviere A, Bardach A. The burden of smoking-related diseases in Brazil: mortality, morbidity and costs. Cad Saúde Pública [Internet]. 2015 [cited 2018 Aug 9];31(6):1283-97. Available from: http://www.scielo.br/pdf/csp/v31n6/en_0102-311Xcsp-31-6-1283.pdf

4. Malta DC, Stopa SR, Santos MAS, Andrade SSCA, Oliveira TP, Cristo EB, et al. Evolution of tobacco use indicators according to telephone 
surveys, 2006-2014. Cad Saúde Pública [Internet]. 2017 [cited 2018 Aug 9];33(3):e00134915. Available from: http://www.scielo.br/pdf/csp/ v33s3/en_1678-4464-csp-33-s3-e00134915.pdf

5. Ministério da Saúde (BR), Secretaria de Vigilância da Saúde, Departamento de Vigilância de Doenças e Agravos não Transmissíveis e Promoção da Saúde. Vigitel Brasil 2015: vigilância de fatores de risco e proteção para doenças crônicas por inquérito telefônico: estimativas sobre frequência e distribuição sociodemográficas de fatores de risco e proteção para doenças crônicas nas capitais dos 26 estados brasileiros e no Distrito Federal em 2015 [Internet]. Brasília: Ministério da Saúde (BR); 2016 [cited 2018 Aug 9]. Available from: http://bvsms. saude.gov.br/bvs/publicacoes/vigitel_brasil_2015.pdf

6. Taylor G, McNeill A, Girling A, Farley A, Lindson-Hawley N, Aveyard P. Change in mental health after smoking cessation: systematic review and meta-analysis. BMJ [Internet]. 2014 [cited 2018 Aug 9];348:1151. Available from: https://www.bmj.com/content/348/bmj.g1151

7. Asma S, Song Y, Cohen J, Eriksen M, Pechacek T, Cohen N, Iskander J. CDC Grand Round: global tobacco control. MMWR Recomm Rep [Internet]. 2014 [cited 2018 Aug 9];63(13):277-80. Available from: http://www.cdc.gov/tobacco/global/index.htm

8. Chatkin JM. Aspectos genéticos do tabagismo. In: Silva LCC. Pneumologia: princípios e prática. São Paulo: Artmed; 2012. p. $215-23$.

9. Chatkin JM. The influence of genetics on nicotine dependence and the role of pharmacogenetics in treating the smoking habit. J Bras Pneumol [Internet]. 2006 [cited 2018 Aug 9];32(6):573-9. Available from: http://www.scielo.br/pdf/jbpneu/v32n6/en_a16v32n6.pdf. http:// dx.doi.org/10.1590/S1806-37132006000600016

10. Reisdorfer E, Gherardi-Donato ECS, Moretti-Pires RO. Meanings of the use of alcohol and tobacco for health professionals. Rev Gaúcha Enferm [Internet]. 2013 [cited 2018 Aug 9];34(4):153-60. Available from: http://www.scielo.br/pdf/rgenf/v34n4/en_20.pdf doi: http://dx.doi. org/10.1590/S1983-14472013000400020

11. Gallus S, Muttarak R, Franchi M, Pacifici R, Colombo P, Boffetta P, et al. Why do smokers quit? Eur J Cancer Prev [Internet]. 2013 [cited 2018 Aug 9];22(1):96-101. Available from: https://insights.ovid.com/pubmed?pmid=22644233

12. Madewell ZJ, Figueiredo VC, Harbertson J, Pérez RL, Novotny Thomas. Exposure to smoking in soap operas and movies: smoking cessation and attempts to quit. Cad Saúde Pública [Internet]. 2017 [cited 2018 Aug 9];33(Suppl 3):e00118015. Available from: http://www.scielo. br/readcube/epdf.php?doi=10.1590/0102-311 x00118015\&pid=S0102-311X2017001505003\&pdf_path=csp/v33s3/1678-4464-csp-33s3-e00118015.pdf\&lang=pt

13. Echer IC, Corrêa APA, Lucena AF, Ferreira SA, Lukasewicz KMM. Prevalence of smoking among employees of a university hospital. Rev LatinoAm Enferm [Internet]. 2011 [cited 2018 Aug 9];19(1):179-86. Available from: http://www.scielo.br/pdf/rlae/v19n1/24.pdf

14. Machado LSF, Rodrigues EP, Oliveira LMM, Laudano RCS, Nascimento Sobrinho CL. [Health problems reported by nursing workers in a public hospital of Bahia]. Rev Bras Enferm [Internet]. 2014[cited 2018 Aug 9];67(5):684-91. Available from: http://www.scielo.br/pdf/reben/ v67n5/0034-7167-reben-67-05-0684.pdf Portuguese.

15. Souza MNM, Martins Júnior DF, Silva, MV, Costa JA, Nascimento Sobrinho CL. [Work and health among professionals of nursing of a hospital specialized in Feira de Santana, Bahia]. Rev Baiana Saúde Pública [Internet]. 2011[cited 2018 Aug 9];35(Supl1):38-54. Available from: http:// files.bvs.br/upload/S/0100-0233/2011/v35nSupl1/a2297.pdf Portuguese.

16. Heatherton TF, Kozlowski LT, Frecker RC, Fagerström K-O. The Fagerström Test for Nicotine Dependence: a revision of the Fagerström Tolerance Questionnaire. Br J Addict. 1991;86:1119-27.

17. Oliveira MS, Ludwig MWB, Moraes JFD, Rodrigues VS, Fernandes RS. [Validity evidences of the University of Rhode Island Change Assessment (Urica-24) for tobacco addicteds/users/smokers]. Rev Ciênc Méd [Internet]. 2014 [cited 2018 Aug 9];23(1):5-14. Available from: https://seer.sis.puc-campinas.edu.br/seer/index.php/cienciasmedicas/article/view/2410/1846 Portuguese.

18. Pawlina MMC; Rondina RC; Espinosa MM, Botelho C. [Anxiety and low motivational level associated with the failure in smoking cessation]. J Bras Psiquiatr [Internet]. 2014 [cited 2018 Aug 9]63(2):113-20. Available from: http://www.scielo.br/pdf/jbpsiq/v63n2/0047-2085jbpsiq-63-2-0113.pdf Portuguese.

19. Luft CB, Sanches SO, Mazo GZ, Andrade A. Brazilian version of the Perceived Stress Scale: translation and validation for the elderly. Rev Saúde Pública [Internet]. 2007[cited 2018 Aug 9]; 41(4):606-15. Available from: http://www.scielo.br/pdf/rsp/v41n4/5932.pdf Portuguese.

20. Paschoal T, Tamayo A. [Validation of the work stress scale]. Estud Psicol [Internet]. 2004[cited 2018 Aug 9];9(1):45-52. Available from: http:// www.scielo.br/pdf/epsic/v9n1/22380.pdf Portuguese.

21. Pereira JCP. Análise de dados qualitativos: estratégias metodológicas para as ciências da saúde, humanas e sociais. São Paulo: Edusp; 2004.160 p.

22. Kuhnen M, Boing AF, Oliveira MC, Longo GZ, Njaine K. Smoking and associated factors in Brazilian adults: a population-based study. Rev Bras Epidemiol [Internet]. 2009[cited 2018 Aug 9];12(4):615-26. Available from: http://www.scielo.br/pdf/rbepid/v12n4/11.pdf Portuguese.

23. Corsi DJ, Subramanian SV, Lear SA, Teo KK, Boyle MH, Joshi R, et al. Tobacco use, smoking quit rates, and socioeconomic patterning among men and women: a cross-sectional survey in rural Andhra Pradesh, India. Eur J Prev Cardiol [Internet]. 2014[cited 2018 Aug 9];21(10):130818. Available from: http://journals.sagepub.com/doi/pdf/10.1177/2047487313491356

24. Smith DR, Leggat PA. [The shoemaker's son always goes barefoot: smoking among heathcare professional]. Rev Bras Saúde Ocup [Internet]. 2014[cited 2018 Aug 9];39(129):1 19-21. Available from: http://www.scielo.br/pdf/rbso/v39n129/0303-7657-rbso-39-129-0119.pdf Portuguese

25. Kim Young-Ju. Predictors for successful smoking cessation in Korean adults. Asian Nursing Research [Internet]. 2014[cited 2018 Aug 9];8(1):1-7. Available from: http://www.asian-nursingresearch.com/article/S1976-1317(13)00057-1/pdf

26. Martinelli PM, Lopes CM, Muniz PT, Souza OF. Smoking in adults in the municipality of Rio Branco, Acre, Brazil: a population-based study. 
Rev Bras Epidemiol [Internet]. 2014[cited 2018 Aug 9];17(4):989-1000. Available from: http://www.scielo.br/pdf/rbepid/v17n4/1415-790Xrbepid-17-04-00989.pdf

27. Scarinci IC, Bittencourt L, Person S, Cruz RC, Moysés ST. [Prevalence of tobacco use and associated factors among women in Paraná State, Brazil]. Cad Saúde Pública [Internet]. 2012 [cited 2018 Aug 9];28(8):1450-8. Available from: http://www.scielo.br/pdf/csp/v28n8/04.pdf Portuguese.

28. Wang Z, Koenig HG, Al Shohaib S. Religious involvement and tobacco use in mainland China: a preliminary study. BMC Public Health [Internet]. 2015 [cited 2018 Aug 9];15:155. Available from: https://www.ncbi.nlm.nih.gov/pmc/articles/PMC4336676/pdf/12889_2015_ Article_1478.pdf

29. Bezerra J, Mauro VGB, Tenório MCM, Tassitano RM, Barros SSH, Hallal PC. [Religiousness, alcohol consumption and smoking in adolescence]. Rev Panam Salud Publica [Internet]. 2009[cited 2018 Aug 9];26(5):440-6. Available from: https://www.scielosp.org/pdf/rpsp/2009. v26n5/440-446/pt Portuguese.

30. Reinaldo MAS, Goecking CC, Silveira BV. Impact of tobacco prevention advertising on cigarette packets on teenagers. Reme [Internet]. 2012[cited 2018 Aug 9];16(3):364-372. Available from: http://www.reme.org.br/exportar-pdf/539/v16n3a08.pdf Portuguese.

31. Ravara SB, Calheiros JM, Aguiar P, Barata LT. Smoking behaviour predicts tobacco control attitudes in a high smoking prevalence hospital: a cross-sectional study a Portuguese teaching hospital prior to the national smoking ban. BMC Public Health [Internet]. 2011 [cited 2018 Feb 13]; 11: 720. Available from: https://bmcpublichealth.biomedcentral.com/track/pdf/10.1186/1471-2458-11-720?site=bmcpublichealth. biomedcentral.com

32. Roque H, Veloso A; Silva I, Costa P. Occupational stress and user satisfaction with primary healthcare in Portugal. Ciênc Saúde Coletiva [Internet]. 2015[cited 2018 Aug 9];20(10):3087-97. Available from: http://www.scielo.br/pdf/csc/v20n10/1413-8123-csc-20-10-3087.pdf Portuguese.

33. Ribeiro L, Gomes A, Silva M. Stress ocupacional em profissionais de saúde: um estudo comparativo entre médicos e enfermeiros a exercerem em contexto hospitalar. In: Nogueira C, Silva I, Lima L, Almeida AT, Cabecinhas R, Gomes R, Machado C, Maia A, Sampaio A, Taveira MC, editors. Actas do VII Simpósio Nacional de Investigação em Psicologia; 2010 Feb 4-6. Lisboa: Associação Portuguesa de Psicologia; 2010. p. 1494-1508.

34. Nunes SOV, de Castro MRP. Tabagismo: abordagem, prevenção e tratamento. Londrina: EDUEL; 2010. 224 p.

35. Russo AC, Azevedo RCS. Factors that motivate smokers to seek outpatient smoking cessation treatment at a university general hospital. J Bras Pneumol [Internet]. 2010[cited 2018 Aug 9];36(5):603-611. Available from: http://www.scielo.br/pdf/jbpneu/v36n5/en_v36n5a12.pdf

36. Bianchini D, Jacob I, Silva T, Silveira C. Tobacco between nursing professionals interior of the hospital in Minas Gerais. Arq Ciênc Saúde [Internet]. 2016[cited 2018 Aug 9];23(4):37-42. Available from: http://www.cienciasdasaude.famerp.br/index.php/racs/article/view/451/235 Portuguese.

37. Sonmez Cl, Aydin LY, Turker Y, Baltaci D, Dikici S, Sariguzel YC, et al. Comparison of smoking habits, knowledge, attitudes and tobacco control interventions between primary care physicians and nurses. Tob Induc Dis [Internet]. 2015[cited 2018 Aug 9];13:37. Available from: https://www.ncbi.nlm.nih.gov/pmc/articles/PMC4642762/pdf/12971_2015_Article_62.pdf

38. Abreu MNS, Caiaffa WT. Influence of family environment and social group on smoking among Brazilian youth aged 15 to 24 years. Rev Panam Salud Pública [Internet]. 2011 [cited 2018 Aug 9];30(1):22-30. Available from: https://www.scielosp.org/pdf/rpsp/2011.v30n1/22-30/pt

39. França SAS, Neves ALF, Souza TAS, Martins NCN, Carneiro SR, Sarges ESNF, et al. Factors associated with smoking cessation. Rev Saúde Pública [Internet]. 2015[cited 2018 Aug 9];49:10. Available from: http://www.scielo.br/pdf/rsp/v49/0034-8910rsp-S0034-89102015049004946.pdf

40. Osler M, Prescott E. Psychosocial, behavioral, and health determinants of successful smoking cessation: a longitudinal study of Danish adults. Tob Control [Internet]. 1998[cited 2018 Aug 9];7(3):262-7. Available from: https://www.ncbi.nlm.nih.gov/pmc/articles/PMC1763896/ pdf/v007p00262.pdf

41. Palloni A, Souza LR, Marteleto LJ. Familial effects on youth smoking in Brazil. Working Paper [Internet]. 2016[cited 2018 Aug 9];146. Available from: https://www.econstor.eu/bitstream/10419/173800/1/869874381.pdf 